\title{
Bioaccumulation Monitoring of Heavy Metal Chromium (Cr) in Fish Oreochromis mossambicus in The Floating Net Cultivation in Sidoarjo Krembangan River
}

\author{
Sonny kristianto, Dina Chamidah \& Laksitarahmi I Pramita \\ Biology Education Department, Faculty of Language and Science, Wijaya Kusuma University, \\ Surabaya, East Java, Indonesia
}

\section{Abstract}

This research aims to investigate the accumulation of heavy metals chromium $(\mathrm{Cr})$ in the flesh of fish oreochromis mossambicus (Oreochromis mossambicus) and find out the feasibility of fish consumption oreochromis mossambicus at floating net on the river Krembangan Sidoaarjo. This research are observatif by using Purposive Random Sampling techniques. test the content of heavy metal chromium $(\mathrm{Cr})$ in the flesh of fish oreochromis mossambicus (Oreochromis mossambicus) method using AAS (Atomic Absorbtion Spectrofotometry). The data generated in the analysis in quantitative descriptive. In this research show that the heavy metal content of chromium $(\mathrm{Cr})$ in the flesh of fish oreochromis mossambicus highs station III of $0.52 \mathrm{mg} / \mathrm{Kg}$; I station of $0.51 \mathrm{mg} / \mathrm{Kg}$ II station of 0.48 $\mathrm{mg} / \mathrm{Kg}$ on a sampling sedangkang the morning, at night the highest value on the station III of $0.50 \mathrm{mg} / \mathrm{Kg}$; I station of $0.46 \mathrm{mg} / \mathrm{Kg}$ and the II of $0.39 \mathrm{mg} / \mathrm{Kg}$. Average deposits of heavy metal $\mathrm{Cr}$ on fish oreochromis mossambicus (o. mossambicus) is still under the raw quality of the already established by the Director-General of POM 1989 i.e. amounted to $2.5 \mathrm{mg} / \mathrm{kg}$ but fall into the category bioakumulasi medium, so that fish oreochromis mossambicus is still worthy of consumption, but need to watch out for, considering the $\mathrm{Cr}$ are toxic, carcinogenic, bioakumulatif and biomagnifikasi would potentially interfere with health.

\section{Article History}

Received 17 September 2018

Accepted 12 December 2018

Keyword

Chromium ( $\mathrm{Cr}$ ),

Oreochromis

Mossambicus fish,

River Krembangan

Sidoarjo

\section{Introduction}

The condition of Bengawan Solo River is currently worrying. Many people have complained about the water condition of this longest and largest river in the island of Java. The results of observations show that, in plain view, the water of Bengawan Solo River looks turbid mixed with mud in the rainy season; while during the dry season, the water is sometimes slightly dark and smelly. Several studies have shown that the water from this river is polluted, and even the content of heavy metals waste is also found. Whereas the Bengawan Solo River is used by some people for their daily needs. The Bengawan Solo River with an average annual rainfall of $2,100 \mathrm{~mm}^{3}$ is a potential water source for management and development efforts of water resources, to meet various needs and requirements such as for 
domestic consumption, for drinking water and industrial, irrigation, and others (Ministry of Public Works, 2010).

The development of Solo City into an industrial city has a negative impact on pollution in the river. There are many industries developing in Solo and its surrounding areas that dispose their waste into the river. Batik (traditional clothing) industry that has become the icon of Solo City on the one hand gives positive value for the economy of society but on the other hand also contributes in river pollution. The efforts conducted by the government, social institution, and the society to solve this issue also seem to have been unsuccessful.

Although with the naked eye, the water of Bengawan Solo River is polluted but in some parts of this River Basin, it is still used by people around for everyday purposes. Based on observations to the River, from the City of Solo to Sragen Regency, activities of people who use water from the River such as bathing, washing, fishing, swimming spot for children, and irrigation of agricultural land can be observed. Water utilization of the Bengawan Solo for irrigation occurs in some areas, one of which is in Sragen. In dry season, the agricultural land in Sragen often suffers from water shortages. People who own rice field near the Bengawan Solo River usually take water from the river for irrigation. They do not have the awareness and concern about the importance of the quality of water used for irrigation, whereas, this issue is related to the quality of their crops.

Based on the background, the water condition of Bengawan Solo River is contaminated with heavy metals waste. But there are still people who use it for daily purposes especially farmers for irrigation. This what prompt the water feasibility study of the Bengawan Solo River for irrigation is conducted and also to find the solution.

\section{Materials and Methods}

This research was carried out at the Time in the village of Krembangan Krembangan in June 2016. Peneltian is using the method of Purposive Random Sampling to measure the quality of Chemical Physics Krembangan river include temperature, $\mathrm{pH}$, dissolved oxygen (DO) and Biochemical Oxygen Demand (BOD) by in-situ on 3 stations with three repetitions with use thermometers, $\mathrm{pH}$ meter and $\mathrm{DO}$ meters. Test the content of heavy metal $\mathrm{Cr}$ on fish Oreochromis Mossambicus (o. mossambicus) method using AAS (Atomic Absorbtion Spectrofotometry) with wavelength $357.54 \mathrm{~nm}$ conducted in the laboratory of research and standardization of Industrial Halls and commercial Surabaya.

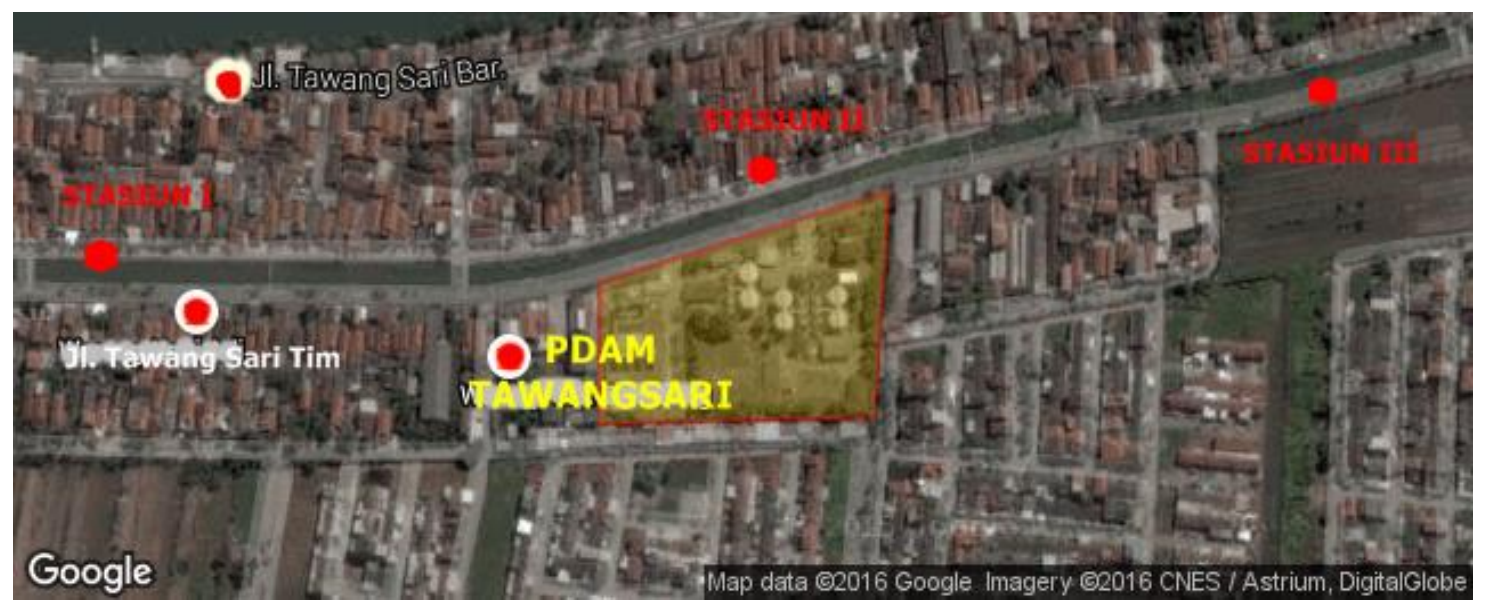

Figure 1. Sampling station 
Chemical Physics quality data streams Krembangan analyzed are descriptive, whereas the determination of the concentration of heavy metal $\mathrm{Cr}$ on fish oreochromis mossambicus (o. mossambicus) Bioconcentration Factor Values calculation using a calculated based on concentration a compound that is in the organism of the experiment divided by the concentration of compounds of heavy metals contained in the medium of water, the unit $\mathrm{Kg} / \mathrm{L}$ Panjaitan (2009).

$$
\mathrm{BCF}=\frac{\text { Content of heavy metals }(\mathrm{Cr}) \text { in the meat of Oreochromis mossambicus }}{\text { Content of heavy metals }(\mathrm{Cr}) \text { on the water }}
$$

According to Amriani et al (2011) the value of the Bioconcentration Factor (BCF) has three categories, namely:

1. The value of the $\mathrm{BCF}>1000 \mathrm{~L} / \mathrm{Kg}$, accumulative nature of high category.

2. The value of the $B C F=100-1000 \mathrm{~L} / \mathrm{Kg}$, accumulative nature of the category are.

3. The value of the BCF $100 \mathrm{~L} / \mathrm{Kg}<$, accumulative nature of low category.

The higher the value of the BCF at an organ, indicating the higher the organs of these heavy metals accumulate Shindu, (2005).

\section{Results and Discussion}

Quality factor of Chemical Physics Krembangan River

The results of the measurement of the quality of Chemical Physics of the Krembangan river include, temperature, $\mathrm{pH}, \mathrm{BOD}$ and $\mathrm{DO}$ at 3 staiun (Table 1 ) shows the value that fluctuates on each factor measurements of temperature, $\mathrm{pH}, \mathrm{d} . \mathrm{o}$. and $\mathrm{BOD}$ on the river Krembangan.

Table 1. The results of the measurement of the physical chemical quality in the Krembangan rivers

\begin{tabular}{lcccc}
\hline \multicolumn{1}{c}{ Variables } & Station & Morning & Afternoon & Late Afternoon \\
\hline Temperature $\left({ }^{\circ} \mathrm{C}\right)$ & 1 & 28.30 & 30.46 & 27.20 \\
& 2 & 28.10 & 30.66 & 26.90 \\
& 3 & 27.90 & 30.50 & 26.80 \\
\hline $\mathrm{pH}$ & 1 & 7.50 & 7.94 & 7.90 \\
& 2 & 7.80 & 8.06 & 8.00 \\
& 3 & 7.90 & 8.03 & 8.00 \\
\hline $\mathrm{DO}(\mathrm{mg} / \mathrm{L})$ & 1 & 2.80 & 2.79 & 2.79 \\
& 2 & 2.78 & 2.79 & 2.69 \\
& 3 & 2.80 & 2.80 & 2.78 \\
\hline $\mathrm{BOD}(\mathrm{mg} / \mathrm{L})$ & 1 & 103.85 & 105.36 & 102.90 \\
& 2 & 104.10 & 105.46 & 103.75 \\
& 3 & 104.02 & 105.40 & 103.80 \\
\hline
\end{tabular}

The results of this study (Table 1 ) shows that the average temperature of the Krembangan River is different at each time taking morning, noon and afternoon on 3 roaming. The average temperature in the morning between 27.9028 .30 - oC, daytime between 30.46 $30.66 \mathrm{oC}-$ and in the evening between $26.20-27.20 \mathrm{oC}$. This is due to the different retrieval time thus affecting the intensity of sunlight that enters into the river Krembangan. An increase in temperature will cause an increase in the speed of your metabolism and respiration of 
organisms water resulting in increased consumption of oxygen. Rising temperatures have also led to an increase in organic matter decomposition by microbes so that concentrations of BOD in water will also increase. The range of optimum temperature for the growth of phytoplankton in waters ranging from $20^{\circ} \mathrm{C}-30^{\circ} \mathrm{C}$ (Effendi, 2003).

Physics $\mathrm{pH}$ factor (Table 1 ) on the river Krembangan have difference at any time taking. The average value of $\mathrm{pH}$ in the morning between 7.90, 7.50 - during the day between $7.94-8.06$ and evening between $8.00-7.90$. This is due to the surrounding communities also use the River as a place of Krembangan household waste disposal so that the $\mathrm{pH}$ has increased. In addition the value of $\mathrm{pH}$ is obtained this is above the normal $\mathrm{pH}$ which is owned by surface water, IE 7.0. This can be caused by the presence of deposits of carbonate and bicarbonate dissolved, which is the deciding factor in surface water $\mathrm{pH}$ (Akoto et al., 2008). Most of the aquatic biota are sensitive to changes in $\mathrm{pH}$ and $\mathrm{pH}$ value of around 7 liked -8.5 (Effendi, 2003). Begum, et al. (2009), the high pH in waters can cause the metal content of terendapkan hydroxide precipitates formed.

Factors (Table 1 ) the average value of a DO on River Krembangan vary at each station. The average value of DO in the morning between $2.78-2.80 \mathrm{mg} / \mathrm{L}$, the daytime between 2.79 $-2.80 \mathrm{mg} / \mathrm{L}$ and the afternoon between $2.69-2.79 \mathrm{mg} / \mathrm{l}$. DO on normal dibandingakan River Krembangan still raw quality of the PPRI No. 82 the year 2001 was $6 \mathrm{mg} / \mathrm{L}$ of oxygen Concentration. dissolved too low an indication that these waters have been contaminated (Azwir 2004). Dissolved oxygen levels also fluctuate daily and seasonal basis, depending on the pollution and movement of water masses, photo synthesis, respiration activity of wastewater into a body of water (Effendi, 2003).

BOD factor (Table 1) the average value of BOD on the river Krembangan differently on each station. On the morning of the average value between $103.85-104.10 \mathrm{mg} / \mathrm{L}$, the daytime between $105.36-105.46 \mathrm{mg} / \mathrm{L}$ and the afternoon between $102.90-103.80 \mathrm{mg} / \mathrm{l}$. BOD on the river Krembangan has exceeded the specified threshold the Government according to the raw quality of the PPRI No. 82-year 2001 is $2 \mathrm{mg} / \mathrm{L}$. This indicates the high oxygen consumed by micro-organisms in waters this species to be able to degrade organic waste that goes into the river Krembangan. The value of BOD are quite high indicating that the river contaminated organic wastes already Krembangan, pendegradasian waste is done in aerobic microorganisms, due to the large number of organic wastes are dumped into waterways causes depletion of levels of dissolved oxygen in the waters, if diminishing oxygen could result in death for aquatic plants, plankton, fish and microorganisms.

Analysis of heavy metal content of $\mathrm{Cr}$, Biokonsentrasi factor, and category Bioakumulasi Fish Oreochromis Mossambicus at Krembangan River

The results of the analysis of heavy metal $\mathrm{Cr}$ on the river and fish flesh Krembangan oreochromis mossambicus (o. mossambicus) (Table 2) method using AAS (Atomic Absorbtion Spectrofotometry) with wavelength $357.54 \mathrm{~nm}$ which is done in laboratories and standardization Research Hall Industry and trade.

Table 2. The Result Analysis of Heavy Metal Cr, Bioconcentration Factor and Bioacumulation Ikan Mujair in The Krembangan Rivers

\begin{tabular}{lccccc}
\hline Time & Station & $\begin{array}{l}\text { Heavy Metal Cr } \\
\text { in Water }(\mathrm{mg} / \mathrm{L})\end{array}$ & $\begin{array}{l}\text { Heavy Metal in } \\
\text { Meat Mujair Fish } \\
\text { (mg/L) }\end{array}$ & $\begin{array}{l}\text { Bioconcentration } \\
\text { Faktor (BCF) } \\
\text { (L/Kg) }\end{array}$ & Category \\
\hline Morning & 1 & 1.17 & 0.51 & 435.89 & Medium \\
& 2 & 1.14 & 0.48 & 421.05 & Medium \\
\hline
\end{tabular}




\begin{tabular}{llllll}
\hline & 3 & 1.20 & 0.52 & 433.33 & Medium \\
\hline Evening & 1 & 0.96 & 0.46 & 479,16 & Medium \\
& 2 & 1.11 & 0.39 & 351.35 & Medium \\
& 3 & 1.03 & 0.50 & 485.43 & Medium \\
\hline
\end{tabular}

The results of the analysis of heavy metal $\mathrm{Cr}$ on Krembangan River shows the difference at each station. The average value of the analysis of heavy metal $\mathrm{Cr}$ on the morning ranged from $1.14-1.20 \mathrm{mg} / \mathrm{L}$ while the evening ranged from $0.96-1.11 \mathrm{mg} / \mathrm{L}$, this is due to the habit of the plant or the person disposing discharge into the river range hours $01.00-$ 02.00 WIB early days. On the morning of the average value of the results of the analysis of heavy metal $\mathrm{Cr}$ is higher than the average value of the analysis of heavy metal $\mathrm{Cr}$ at night because on the morning of the waste has already spread following the flow of the river. Heavy metal contamination in rivers can occur due to Sidoarjo Krembangan disposal of domestic waste and waste industrial result dumped into River Krembangan Sidoarjo without first being processed or processed but still above the levels of quality raw polutannya the set. The metals in the aquatic environment are generally in the form of ions, there is a free ion, ion pair organic complex ions, and other ions form. Although the levels of heavy metals in water is relatively small, but very easily absorbed and accumulated biologically by plants or aquatic animals and will be involved in the system of food webs. This has led to a process of bioakumulasi i.e. heavy metals will be accumulated and increased simply applied in aquatic organisms, including fish oreochromis mossambicus, then through the transformation will happen moving and elevated levels of heavy metals indirectly through the food chain (Damandiri 2006). According to the Palar (2004) the solubility of elements - elements of heavy metals in water bodies in control by $\mathrm{pH}$, type and concentration of metals and minerals ability, State of khelat teroksida and redox system of berlingkungan.

The results of the analysis of heavy metal $\mathrm{Cr}$ on fish oreochromis mossambicus $(O$. mossambicus) shows the difference at each station. The results of the analysis of heavy metal $\mathrm{Cr}$ on fish oreochromis mossambicus which was taken on the morning of between $0.48-0.52$ $\mathrm{mg} / \mathrm{L}$, while in the evening between $0.39-0.50 \mathrm{mg} / \mathrm{l}$. Value Analysis of heavy metal $\mathrm{Cr}$ on fish oreochromis mossambicus (o. mossambicus) has not exceeded a threshold according to the Director-POMS No. 03725/B/SK/about the limits of Metal Impurities on food, namely of 2.5 $\mathrm{mg} / \mathrm{kg}$, but although it has yet to go beyond the threshold of heavy metal $\mathrm{Cr}$ on fish oreochromis mossambicus (o. mossambicus) still need to look out for in the long run because heavy metals are toxic and carcinogenic $\mathrm{Cr}$.

Results of the analysis of the biokonsentrasi factors of heavy metal $\mathrm{Cr}$ on fish oreochromis mossambicus (o. mossambicus) shows the difference. On the morning of the average value of heavy metal $\mathrm{Cr}$ biokonsentrasi analysis between $421.05-435.89 \mathrm{~L} / \mathrm{Kg}$, the night between 351.35 - L/Kg 485.43. Bioakumulasi heavy metal $\mathrm{Cr}$ on fish oreochromis mossambicus (o. mossambicus) reached bioakumulasi levels are categories, it is because fish oreochromis mossambicus (o. mossambicus) is a predator. In addition the sample fish oreochromis mossambicus (o. mossambicus) taken to be analyzed the content of heavy metals have already entered a period of harvest so that ensured accumulation of heavy metal $\mathrm{Cr}$ on high, it is seen from the size and weight of fish oreochromis mossambicus (o. mossambicus). Age is also one of the factors that influence the length of exposure to toxic substances in the organism, although fish in general have the ability to prevent themselves from the influence of the pollution, but if fish habitats is limited as in Floating Net will be difficult to prevent themselves from pollution, this has resulted in the presence of elemental accumulation polluters including heavy metals into the body of the fish (Dinata 2006). 
Generally there are 4 ways of heavy metals accumulate in the body tissues of fish through the water flow in the gills, the process of eating and drinking as well as skin, Lasut, (2009). Accumulation of heavy metals in fish begins with the process (uptake) through the gills and then absorbed into the body of the fish and the entire network system level excretion of Akbar, (2002). From the results of the analysis of the bioakumulasi heavy metal $\mathrm{Cr}$ on fish oreochromis mossambicus (o. mossambicus) at floating net cultivation in the Krembangan fall into the category bioakumulasi are so lacking in long-term consumption is advised.

\section{Conclusions}

The quality of Chemical Physics include temperature, $\mathrm{pH}, \mathrm{d}$.o. and BOD on the River have entered the category Krembangan tainted with high levels of pollution, it is It can be seen from the results of measurements of the physical and chemical quality of rivers Krembangan who has beyond the limits set by the Government. The content of heavy metal $\mathrm{Cr}$ on Krembangan River have also exceeds the limit set by the Government, although the content of heavy metal $\mathrm{Cr}$ on fish oreochromis mossambicus (o. mossambicus) has not exceeded limits set by BPOM amounted to $2.5 \mathrm{mg} / \mathrm{Kg}$ but to consume fish oreochromis mossambicus in the floating net cultivation in the Krembangan in the long term is less recommended, this is due to the level of bioakumulasi belongs to the category bioakumulasi.

\section{References}

Ackerley, D.F, Gonzales.C.F, Park, C.H, Blake,R. Keyhan,M.\& Martin,A.2004. Chromat Reducing Properties of Soluble Flavoprotein from Pseudomonas putida and Escherichia coli." Applied and Environmental Biology". 70.(2): 873-882.

Akbar HS. 2002. Prediction of heavy metal Accumulation rates of $\mathrm{Cd}, \mathrm{Pb}, \mathrm{Cu}, \mathrm{Zn}$ and $\mathrm{Ni}$ in Mussels (Penna viridis $L$ ) size $>5 \mathrm{~cm}$ in the waters of the estuary, the Bay of Jakarta's Kamal [in Indonesia]

Akoto, O., Bruce, T. N., Darkol, G. 2008, Heavy metals pollution profiles in streams serving the Owabi reservoir. African Journal of Environmental Science and Technology, 2 (11) : 354-359.

Amriani, Hendrarto B \& Hadiyarto A. 2011. Bioaccumulation of heavy metals lead ( $p b$ ) and zinc $(\mathrm{Zn})$ in the blood Cockle (Anadara granosa I.) and Mangrove Shells (Polymesoda bengalensis I.) in the waters of the Gulf of Kendari. Journal of environmental science, 9 (2): 45-50. [in Indonesia]

Baolin D., Ian, L., Houston, k., Brady, PV.,2003, Effect Clay Minerals on Cr (VI) Reduction by Organic Compounds, Environmental Monitoring and Assesment. 84 : 5-18.

Begum, A., Ramaiah, M., Harkrishna, S., Khan, I., Veena, K., 2009b, Heavy Metal Pollution and Chemical Profile of Cauvery River Water, E-Journal of Chemistry, 6 (1) : 47-52.

Connel, DW and g. j. Miller. 1995. Ekotoksikologi chemistry and Pollution. UI Press., Jakarta. [in Indonesia]

Connell, d. w. and G.J. Miller. 2006. Ekotoksikologi chemistry and Pollution. Jakarta: Indonesia University. [in Indonesia]

Effendi, H. 2003. Study of water quality For resource management and the aquatic environment. The Publisher Of Canisius. Yogyakarta.[in Indonesia]

The decision of the Director General of the food and drug Supervision number: 0375/B/SK/VII/89 Concerning the limits of Maximum Metal Impurities in food. [in Indonesia] 
Larashati, s. 2004. The reduction of Chromium ( $\mathrm{Cr}$ ) In In Vitro By a mixed culture of Bacteria In isolation from Lindi Landfill Waste (LANDFILL). ITB. [in Indonesia]

Mulyani, b. 2004. Analysis of the variation of Biomass Saccharomyces cerevisiae Against Chrome Metal Absorption. Sain. 2 (4): 1-9. [in Indonesia]

Palar, h. 2008. Pollution and Toxicology of heavy metals. Publisher Copyright Rineka, Jakarta. 152 page. [in Indonesia]

Government regulation of the Republic of Indonesia Number 82 of the year 2001. About water quality Management and control of water pollution. [in Indonesia]

Schiavon, M. E. A. H. Pilon. Smits, M. Wirtz, R. Hell and M. Malagoli. 2008. Interactions Between Chromium And Sulfur Metabolism In Brassica juncea. Journal of Enviromental Quality. 37 : 1536-1545.

Shindu SF, 2005. Heavy metal content of $\mathrm{Cu}, \mathrm{Zn}$ and $\mathrm{Pb}$ in water, fish Tilapia (Oreochromis niloticus) and carp (Cyprinus carpio) in the floating net, Reservoirs Saguling. Institute of Holticulture Bogor. [in Indonesia]

The legislation of the Republic of Indonesia No.32 year 2009 on the protection and management of the environment.[in Indonesia] 